\author{
Adam Olczyk \\ Katedra Teorii i Filozofii Prawa \\ Uniwersytet Łódzki \\ adam.tomasz.olczyk@gmail.com
}

\title{
Czym jest hejt? Kilka słów o werbalnej nienawiści
}

\section{Wstęp}

Cieszące się niemałą popularnością w istotnej części diagnoz współczesnej debaty publicznej pojęcie hejtu wykazuje pewne podobieństwo z takimi terminami, jak: utopia, foton, mem czy lans. Punkt zbieżny ulokowany jest w tym przypadku w historycznej (czasowej) relacji między zaistnieniem wyrazu w powszechnej praktyce użytkowników języka a tym, do czego się odnosi: wymienione terminy mają intencje określać zjawiska, które były żywo obecne, zanim w ogóle pojawiły się słowa właściwie je nazywające. Nikt rozsądny nie będzie protestował, gdy powiemy, że na długo przed Thomasem More’em jakąś wizję u topii znaleźć możemy w d ziełach Platona, podobnie nie wydaje się nadużyciem stwierdzić, iż Schopenhauer był gorliwym hejterem twórczości Hegla. Mamy tu więc do czynienia z ponadczasową formą aktywności, z trwałym zjawiskiem, dla którego w pewnym dającym się mniej więcej określić momencie wymyślono odpowiednią nazwę (Kołakowski 2011: 9). Można odnotować, że w przypadku hejtu (podobnie sprawa ma się przy „lansie”) nie sposób wskazać datę i autora wypowiedzi, w której po raz pierwszy użyto tego pojęcia w języku polskim w znaczeniu przynajmniej zbliżonym do tego, 
w jakim rozumiane jest dzisiaj, i w powstałych w przyszłości podręcznikach będzie się zapewne korzystało z ogólnej formuły: „hejt — słowo, które wyłoniło się na początku dwudziestego pierwszego wieku dla opisania pewnego fenomenu towarzyszącego werbalnej komunikacji międzyludzkiej, zwłaszcza tej odbywającej się w internecie", czyli stosując nieostre kryterium w postaci nietraktowanych sztywno barier temporalnych.

$\mathrm{W}$ takich przypadkach nieodparcie narzuca się pytanie o to, jakie właściwości wyróżnionego okresu stoją u podstaw tego, że akurat w tym, a nie innym momencie dane pojęcie zyskuje na popularności. Często samo zaistnienie słowa świadczy o swoistym fenomenie mówiącym nam coś o kulturze, w której się pojawiło (nie zawsze, bo nie jest tak np. przy wyspecjalizowanych nazwach technicznych). Termin celebryta nie tylko wyróżnia nową kategorię, która pozwala badaczom lepiej opisywać rzeczywistość społeczną - sama okoliczność jego wystąpienia oraz idąca w parze praktyka stosowania wnoszą pewną wartość dodaną do tego, co wiemy o świecie.

Nie inaczej jest $z$ hejtem. Zwrócić można przy tym uwagę, że termin ten $z$ nienawiścią łączy nie tylko ewidentny związek znaczeniowy (pochodzenie od angielskiego słowa hate „nienawiść”), ale również pewne właściwości towarzyszące zabiegom opisującym. W przypadku takich rozważań najczęściej bowiem - podobnie jak czynić chciał Sokrates w rozmowie z Diotymą, gdy dysputowali o miłości (Platon 1957: 102-121) - rozmowa dotyczy nie nienawiści czy hejtu „jako takich", ale ich przedmiotu i źródeł. Bogata literatura odnosząca się do doświadczeń poprzedniego wieku zwyczajowo nie traktuje o tym, czym właściwie jest nienawiść, skupiając się na tym, co ją warunkuje (tak w zakresie jednostkowym, jak i wobec sieci zależności społecznych) oraz na tym, gdzie energia ta znajduje upust, dlaczego wybiera określone byty za obiekt swojego działania. Takie rozważania oczywiście w jakiś sposób udzielają odpowiedzi na pytanie, czym coś jest, jednak w kontekście, który w drugiej kolejności interesuje filozofa - ten bowiem będzie dopytywał o istotę, o to, co stanowi sedno rozpatrywanego terminu, jego esencję niezależną od akcydensów.

Podobnie dyskusja wokół hejtu wydaje się jednoznacznie koncentrować na jego przyczynach, przejawach i skutkach, nie bardzo troszcząc się o to, czym właściwie on jest. Lukę tę stara się uzupełnić niniejszy wywód. W dalszej części staram się abstrahować przeto od rozważań, co leży u podstaw zjawiska hejtowania, skąd ono się wzięło i jakie są jego konsekwencje, biorąc jednak pod uwagę kwestię obecności hejtów w dyskursie - w tym zakresie, w jakim wskazuje ona na istotne cechy analizowanego słowa. Ważkie są w tym zakresie rozważania co do samej nienawiści. Wobec zdawkowych i raczej niewystarczających definicji hejtu, 
nieznajdujących na ogół oparcia we wnikliwszych rozważaniach, proponuję tym samym sposób, w jaki można termin ten w języku polskim rozumieć, w oderwaniu jednak od zagadnień, które tradycyjnie zwykły stanowić przedmiot zainteresowania etymologów. Niniejsza próba pełnić ma więc rolę projektującą. W tym celu, niezbicie, potrzebne są odpowiednie zabiegi sprawozdawcze - przedstawiane one będą w dalszej części na tyle, by udało się osiągnąć spójność między postulowanym rozumieniem hejtu a tym, które intuicja autora odnajduje w wypowiedziach użytkowników języka polskiego. Wyrażam przy tym nadzieję, że intuicja ta będzie odpowiadała jakimkolwiek, choćby nieuświadamianym, sposobom pojmowania hejtu.

\section{Hejt - językowa nienawiść}

Najprościej powiedzieć, że hejt to taki komunikat językowy, w którym zawarta jest nienawiść skierowana ku temu, do czego komunikat ten się odnosi. Do hejtu przynależy zatem pewna szczególna cecha, którą można wypowiedziom przypisywać bądź nie. Uciążliwość związana z tą klasyfikacją jest oczywista, gdy tylko spostrzeże się, że odnosi się ona do niejasnej kategorii nienawiści, przynależnej sferze uczuć, w której wiele zjawisk bytuje w sposób nieuświadomiony.

Nienawiść tradycyjnie przeciwstawiana jest miłości i faktycznie zestawienie to daje nam pewien jej obraz, słusznie jednak wskazuje Leszek Kołakowski, że stosunek między nimi nie jest symetryczny (Kołakowski 1990: 94). Nienawiści nieobca jest gorliwość i zapał, ograniczają się one jednak do destrukcji i zadawania cierpienia, nie towarzyszy jej twórcza werwa, przynależna sferze miłości. Obywatele państwa komunistycznego mają nienawidzić burżuazji i zwalczać wszelkie przejawy myśli mieszczańskiej, jednakże w założeniu wszelka działalność (zwłaszcza publiczna) winna odbywać się w poczuciu umiłowania socjalistycznych ideałów i w porywie nadziei na zrealizowanie postulowanego wzoru.

Kołakowski poucza, że w nienawiści nie chodzi też o wolę zniszczenia, ale o dążenie do zadania nieustającego cierpienia - to nienasycenie podobne miłości, to namiętność nie do zaspokojenia, nieznajdująca spokoju. Jak każdemu z ludzkich uczuć, przychodzi jej mierzyć się z czasem, z jego biegiem wzrasta i cichnie, nierzadko umiera. Jak długo jednak trwa, pozornie tylko bierze pod uwagę względy, które ją przekraczają. Zachowanie hejtowanego jest dla nienawiści hejtera obojętne; choćby się przyznał do błędu, wyrzekł poglądu, zmienił stanowisko, przeprosił - hejtera nie syci żadna forma upadku jego ofiary. Orzeczony wyrok nie 
zmienia swej treści wraz z ujawnieniem się nowych dowodów; w takiej sytuacji hejter zawsze znajdzie kolejną przyczynę nienawidzenia, choćby miało to nastąpić kosztem konsekwencji i spójności głoszonych przezeń poglądów. W pewnej skali obrazuje to dyskurs podejmowany przez polityków wrogich ugrupowań - i tutaj tworzy się pozór racji, które uzasadniać mają sądy z dawna rozstrzygnięte.

\section{Przypadkowość}

Podobnie jak miłości nienawiści nie sposób wyprowadzić z reguł sprawiedliwości (Kołakowski 1990: 93). Możemy mówić o kimś, że zasługuje na miłość albo że winien tym uczuciem darzyć określoną osobę, nie rozumiemy jednak przez to, iż istnieje niechybny wzór na miłość, bezwzględny imperatyw, który dałby się symetrycznie określić i z którego wynikałoby, co należy zrobić, by na miłość zapracować tak, jak świadczonymi usługami zapracować można na wynagrodzenie. Tylko bowiem mocą prawa - które tu nie działa, miłość nie jest objęta jego kognicją - można na cokolwiek zasłużyć. Zwykliśmy potępiać matkę, która nie kocha swojego dziecka, jednak - trywialne to spostrzeżenie - nie mamy środków, by skutecznie ją do tego uczucia przymusić.

Uwagi te należy uzupełnić o spostrzeżenie, że chociaż brak koniecznej zależności między jakimkolwiek działaniem a nienawiścią (miłością), to jednak istnieją reguły pozwalające wierzyć, iż mocą swoich czynów jesteśmy w stanie zwiększać szanse bycia nienawidzonym albo kochanym. Atrakcyjny wygląd, tożsamość niektórych przekonań, więzy krwi, wspólna przeszłość, tak jak odpowiednia strategia marketingowa towarzysząca wprowadzeniu nowego produktu na rynek, nie pozostają bez wpływu na prawdopodobieństwo powodzenia. Podobnie z nienawiścią. Doświadczenie uczy, że przyczynia się doń np. brak zabiegów asymilujących jakąś mniejszość $\mathrm{z}$ kulturą $\mathrm{w}$ danym kręgu dominującą - to w wymiarze generalnym, $\mathrm{w}$ indywidualnym natomiast $\mathrm{z}$ całą pewnością szanse bycia znienawidzonym intensyfikuje uzyskanie medialnego rozgłosu. Nie wydaje się przy tym, że sprawa sprowadza się w prosty sposób do wystawienia na świecznik, że w związku z uzyskaniem statusu gwiazdy (celebryty) jesteśmy poddawani ocenie przez większe gremium niż osoby niecieszące się specjalną sławą i tym, co zmienia się w takim przypadku, jest nie ułamek osób, które nas nienawidzą, a tylko ich liczba. Sława jako taka jest samodzielnym czynnikiem, który zwiększa szansę bycia przedmiotem nienawiści. I nie chodzi tu także o to, że osoba znana musi mierzyć się ze stosunkowo większą liczbą tych, które wiedzę na jej temat mają tylko fragmentaryczną. W życiu osób nieznanych również jest tak, że często myślą o nich i mówią 
ludzie, którzy wiadomości na ich temat czerpią bardziej z relacji innych i tego, co od innych posłyszeli, niźli z osobistego, bezpośredniego obcowania - mimo że i w takim przypadku wizerunek jest zniekształcony pośredniością przekazu faktów i opinii, nie prowokuje on jednak intensywnej nienawiści; raczej prowadzi do obojętności. Nie, chodzi tu o pewną niechęć, która pojawia się wraz z estymą, niechęć motywowaną między innymi zazdrością, idącą w parze z pomysłem, że sława jest przypadkowa, a przez to niesprawiedliwa i „równie dobrze to przecież mogłem być ja”.

Rozważania te nie mają jednak podważać podstawowej w tym zakresie okoliczności - tego, że ostatecznie w charakterystykę nienawiści wpisana jest przypadkowość. Wydaje się, że często nie rozumieją tej przypadłości celebryci, którzy z niedowierzaniem spoglądają na falę hejtu, zalewającą ich internetowe profile i wszelkie wiadomości, których są bohaterami. Podejmowane są przy tym próby zrozumienia owej przypadkowości, jednak mają one charakter wtórny, niczym wyliczenia ekonomistów po krachach giełdowych. Tutaj mała uwaga: bezspornie perspektywa deterministyczna uniemożliwia przyjęcie opcji przypadku, w niniejszym rozumieniu chodzi o praktyczny brak możliwości wzięcia pod uwagę wszelkich okoliczności i przewidzenia ich skutków.

I tak, o ile można doszukiwać się w miarę sensownych tłumaczeń wyjaśniających swoistą wręcz modę na hejtowanie Justina Biebera, to w przypadku zespołu Nickelback dobór przesłanek wydaje się nieodgadniony i trudno oprzeć się wrażeniu, że z równym powodzeniem mogła to być inna podobna muzyczna kapela. Podobnie rzecz ma się z Paulem Coelho - jakkolwiek charakter jego twórczości zestawiony z popularnością wydaje się $\mathrm{w}$ oczywisty sposób sprzyjać licznym memom wyśmiewającym wzniosłość wygłaszanych przez niego hasłowych prawd życiowych, to już fala nienawiści wylewana w stronę tego pisarza przymiot oczywistości traci. Podając przykłady z polskiego podwórka, takie jak internetowe fenomeny hejtu, którego ofiarami byli: Tomasz Karolak, raperzy kojarzeni z nurtem hip-hopolo czy Janusz Ławrynowicz, dzielnicowy z Pasłęku, który nie tylko został twarzą popularnego mema Typowy Andrzej (względnie: Typowy Janusz), ale który musiał mierzyć się z nienawiścią, jaka wskutek popularności spotkała go w okolicy (Majdan 2012: b.s.), nie sposób znów nie dzielić uczucia, że mógł to być ktokolwiek inny. Każdy z tych przypadków można dziś wyjaśnić, żadnego jednak nie sposób było przewidzieć.

Przy zetknięciu z nienawiścią prawie zawsze pojawia się chęć jej wyjaśniania i usprawiedliwienia, których to potrzeb nie odczuwamy w takim stopniu przy uczuciach pozytywnych. Gdy oznajmiamy, że kibicujemy jakiejś drużynie piłkarskiej, lubimy placki ziemniaczane i kochamy Olę, raczej nie pytają nas: „Dlaczego?”. 
Wyjaśnienia takie czasem się pojawiają, obracają się jednak na ogół wokół utartych schematów: „bo jest wspaniały”, „bo najlepszy”, „i zdecydowanie najpiękniejszy”. Gdy powiemy jednak, że życzymy źle koledze z roku, nie smakujemy w maślance albo nienawidzimy Czechów, pojawia się niejaki przymus wyjaśnienia, motywowany - w przypadku nienawiści - między innymi chęcią usprawiedliwienia własnej niegodziwości. Miłość bowiem uszlachetnia, a nienawiść upadla. Chcemy tedy ze swego upodlenia zdać notę sumitującą, gdy tymczasem jego podstawy są nieracjonalne - w tym sensie, że nie poddają się rozumowym kryteriom.

Toteż hejter najczęściej nie chce być nazywany hejterem. Deklarując bycie hejterem, w przypadku podjęcia argumentacji, skazani jesteśmy na przyznanie, iż uzasadniamy wyrok, który już zapadł, a którego sentencja została dobrana w sposób przypadkowy. Celnie podnosi Wisława Szymborska, że nienawiść: „Sama rodzi przyczyny, / które ją budzą do życia" (Szymborska 1997: 147). Stąd próby oparcia nienawiści w ideologii - częściowo zawodne, doktrynie bowiem łatwiej tłumaczyć, dlaczego warto eksterminować Romów, niźli czemu należy ich przy tym koniecznie nienawidzić. Zwrócić także można uwagę, że do eksplikacji dążą nie tylko sprawcy, ale i ofiary - usensownienie nienawiści, z jaką się spotykają, jest $\mathrm{w}$ tym wymiarze kolejną $\mathrm{z}$ beznadziejnych ludzkich prób przeżywania świata jako nieprzypadkowego (Kołakowski 1986: 18).

\section{Hejt — komunikat językowy}

Wobec tego, co powyżej stwierdzone, hejt jest takim komunikatem językowym, w którym zawiera się niejasna kategoria nienawiści. Z drugiej strony, w duchu platońskim powiedzieć można, że każdy hejt jest niejako odbiciem wiecznej idei nienawiści (o ile taka może w ogóle istnieć); jest sposobem, w jaki namiętność ta przedstawia się w zmysłowym świecie. Nienawiść jednako jawić może się pod wieloma postaciami, także niewerbalnymi. Odnajdujemy ją w czynach, obrazach, milczeniu. Uważam, że sposób, w jaki użytkownicy języka polskiego używają terminu „hejt”, każe wiązać go jednak tylko z aktami języka, tak pisanymi, jak mówionymi - brak więc tutaj ograniczenia pola jego występowania do internetu. Oczywiście można również hejtować w języku migowym. Nigdy nie będzie natomiast hejtem swastyka, nie jest nim uderzenie chrześcijanina w nos - za to tylko, że wierzy w Jezusa. Podobnie karykatury Mahometa umieszczane w duńskim dzienniku Jyllands-Posten i francuskim Charlie Hebdo - nawet gdyby założyć, że towarzyszył im nienawistny przekaz. Brak jednak innej racji dla takiego określenia hejtu niźli poparty intuicją subiektywny wybór. 
Zwrócić jeszcze można uwagę, że klasyfikując komunikat jako hejt, należy wystrzegać się błędu zaliczania do tej kategorii wypowiedzi, które są „tylko” przejawem słownej agresji bądź wulgaryzmami. Agresja często towarzyszy nienawiści, stąd może ona nierzadko być jednym z czynników świadczących o tym, że dany akt językowy jest hejtem, jednak zakresy desygnatów tych wyrażeń pozostają w stosunku krzyżowania. Hejty mogą być wypowiadane na chłodno, bez agresji, jak spokojne życzenie komuś śmierci jego bliskich. Natomiast nie każda słowna agresja, np. wykrzykiwanie przez wzburzoną żonę deklaracji o nienawidzeniu małżonka, świadczy o jej odczuciach, a tym samym każe klasyfikować takie słowa jako hejt. Podobnie, nawet wyraźniej, sprawa ma się z wulgaryzmami - nie ma wątpliwości, że umieszczenie w wypowiedzi przekleństwa nie świadczy koniecznie o hejcie.

Nie sposób też zgodzić się z twierdzeniem, że łatwiej hejtować niż nienawidzić (Bobrowicz 2015), chyba że rozumieć przez to tyle tylko, iż środki wyrazu hejtu są łatwiejsze. „Uprawiać hejt” znaczy właśnie tyle, co „uprawiać nienawiść”, choć w ograniczeniu do językowej formy przekazu. Inną jeszcze kwestią jest intensywność namiętności, trzeba pamiętać bowiem, że żar nienawiści (miłości) płonąć może różnym ogniem, o niejednakowym stopniu natężenia.

\section{Hejt a mowa nienawiści}

Zajmując się hejtem, warto zestawić ten termin z pojęciem mowy nienawiści. Jest to określenie o dłuższej historii, zawarte w regulacjach prawnych niektórych państw, a przez to zdecydowanie lepiej opisane w literaturze. Można w tym zakresie wskazać na definicję zaprezentowaną w unijnej Rekomendacji R (97) 20, która powiela sposób powszechnie przyjęty przy określaniu znaczenia mowy nienawiści (Recommendation: 2). Na schemat ten składają się dwa człony. Jednym z nich jest wyróżnienie pewnych powszechnie krytykowanych w kręgu kultury europejskiej idei. Katalog ten bywa różnie ujmowany, np. trochę inaczej niż w Rekomendacji, w art. 256 obowiązującego Kodeksu karnego (dalej „k.k.”), z którym niektórzy autorzy wiążą - niebezzasadnie zresztą ${ }^{1}$ - pojęcie mowy nienawiści z polską regulacją prawną, wymienione są: faszystowski lub inny totalitarny ustrój państwa oraz nienawiść na tle różnic narodowościowych, etnicznych, rasowych, wyznaniowych albo ze względu na bezwyznaniowość. Drugim elementem jest wyliczenie zachowań,

\footnotetext{
1 Jakkolwiek polski Kodeks karny nie wyróżnia kategorii mowy nienawiści, to określenie takie pojawia się w literaturze, kojarzone np. z art. 256, 257 czy art. 196 k.k.
} 
które polegają na wydaniu komunikatu sugerującego, iż idee te przynajmniej nie są godne potępienia, a często nawet, że niosą ze sobą pozytywne wartości, że zasługują na aprobatę. W omawianym artykule polskiego kodeksu karnego mowa jest o propagowaniu i nawoływaniu, czyli o działaniach afirmujących określone poglądy w sposób bezpośredni. We wskazanej rekomendacji wymieniono natomiast już samo choćby ich usprawiedliwianie (justify).

W dyskusjach, w których pojawia się zagadnienie hejtu, nie tylko często pada ono obok mowy nienawiści - wielokrotnie używa się tych pojęć zamiennie. Mimo pewnych różnic mowa nienawiści jest w miarę jednolicie rozumiana, zaś niespójności w jej określaniu mają bądź to charakter aprioryczny i wynikają z przyjęcia różnych definicji, bądź też są wynikiem odmiennych poglądów wyrażanych w literaturze, wynikających z rozbieżnych interpretacji, jednakże przyjmujących pewne wspólne założenia co do istoty spornego terminu, choćby poprzez przyporządkowanie go sferze obejmującej określone kwestie. W tym drugim przypadku mowa nienawiści dzieli losy wszystkich właściwie pojęć, które zajmują myśli przedstawicieli nauk humanistycznych, a których to rozumienie - poza wąskim gronem specjalistów - nie prowokuje większych wątpliwości.

Hejt z kolei jest terminem, który nie tylko nie występuje na gruncie regulacji prawnych, ale także per se stanowi stosunkowo nowe zagadnienie dla reprezentantów różnych dyscyplin naukowych, choćby: kulturoznawców, socjologów, medioznawców czy filozofów. Zastrzec można przy tym, że na gruncie prawa amerykańskiego funkcjonuje kategoria zbrodni nienawiści (hate crime), która nie jest bez związku z mową nienawiści (hate speech), jednakże ewentualna relacja tego rodzaju przestępstw z tym, co mają na myśli użytkownicy języka polskiego, gdy mówią o hejtowaniu, ma charakter wtórny wobec podstawowego ustalenia, czym w ogóle hejt jest.

Uprzedzić również trzeba, że jakkolwiek można mówić o hejtach, które nie są mową nienawiści, i przeciwnie, spotyka się takie wypowiedzi, które stanowią mowę nienawiści, nie będąc jednocześnie hejtami, to nakreślenie ostrego, sztywnego rozgraniczenia w tym zakresie jest niezasadne i każda taka próba byłaby sztuczna. W wielu przypadkach zakresy desygnatów obu pojęć pokrywają się. Czynniki odróżniające oba terminy są bowiem pewnymi kierunkami, w stronę których, bardziej lub mniej, są one zwrócone; nic przy tym nie stoi na przeszkodzie, by komunikat był jednako ustosunkowany do obu z nich. Wyznaczenie toru uzależnione jest od dwóch aspektów: po pierwsze, od stosunku względem zbiorowości i jednostki; po drugie, od czegoś, co można nazwać zapleczem ideologicznym. 


\section{Ukierunkowanie na jednostkę}

Jeżeli chodzi o pierwszy z aspektów, warto wskazać na stwierdzenie Michała Kućki oraz Katarzyny Pałki: „Celem mowy nienawiści jest zawsze zbiorowość. Nawet jeśli pozornie jej adresatem jest jednostka, w rzeczywistości podmiotem atakowanym jest wyróżniona w oparciu o cechy społeczne lub biologiczne grupa" (Kućka, Pałka 2010). W przypadku hejtu jest dokładnie odwrotnie: to jednostka jest jego przedmiotem, to przeciw niej skierowane jest ostrze hejtera. $\mathrm{W}$ tym zakresie hejt jest niejako skutkiem mowy nienawiści, która wzywa do tego, by nienawidzić, usprawiedliwia nienawiść, często wyposażając w zaplecze o quasi-intelektualnym charakterze. Hejt natomiast nie tyle jest nawoływaniem do nienawiści, co samą już nienawiścią, jej przejawem, to odbicie idei, konkretny przejaw czegoś, co samo w sobie jest abstrakcyjne, generalne, ogólne.

W zgodzie z tym mowa nienawiści, podobnie jak normy zawarte w konstytucji, $\mathrm{w}$ ustawach, czy traktatach międzynarodowych, nie indywidualizuje podmiotu. U jej podstaw znajdują się ogólne twierdzenia mające aspiracje bycia równie prawdziwymi dzisiaj, co w hipotetycznej sytuacji, w której na Ziemi przy życiu zostałby jeden tylko człowiek. Z takiego zestawu racji wyciąga się kolejno wnioski o charakterze normatywnym, np. na bazie stwierdzenia zależności między kolorem skóry a ilorazem inteligencji konstruuje się normę, z której wynika zasada podrzędnego traktowania mniej inteligentnych (tutaj wtrącić można, że sprawa komplikuje się w przypadku podobnych wyników na tle narodowościowym, wtedy też zasada „mniej inteligentnego należy gorzej traktować” często przestaje obowiązywać).

Hejt jest natomiast konkretyzacją generalnie i abstrakcyjnie wyrażonej reguły, wypowiedzią odnoszącą się do indywidualnie oznaczonego podmiotu, przybierającą np. postać: „Włodek, ty durny czarnuchu”. Celem, ku któremu ukierunkowuje się nienawiść, jest tutaj osoba, w stronę której zwrócony jest komunikat. W przykładzie to Włodka mają zaboleć wyrażone słowa, nie jest to nawołanie do tego, by nienawidzić wszystkich osób należących do klasy, do jakiej go przypisano. U celu takiej wypowiedzi znajduje się zamiar sprawienia cierpienia indywidualnie określonemu podmiotowi. Nie musi przy tym być to jedna tylko osoba, ale np. członkowie grupy, wyróżnieni nie tyle właściwą jej tylko ogólną cechą (np. byciem słuchaczem muzyki disco polo), co w sposób pozwalający bezpośrednio i jednostkowo oznaczyć jej członków, np. mieszkająca za płotem rodzina z dziećmi albo wyjściowy skład Realu Madryt w finale Ligi Mistrzów w 2014 roku. Tym samym, gdyby np. założyć, że wszyscy Żydzi zginęli w czasie drugiej wojny światowej, niemożliwe byłoby dziś ich hejtowanie i można by wtedy tylko powiedzieć, że wszelki pokład werbalnych przejawów antysemityzmu wyczerpuje się w mowie nienawiści. 


\section{Zaplecze ideologiczne}

Ze wskazanej wyżej wypowiedzi (przykładu) można wnosić, że jej autor jest rasistą i w wielu przypadkach pewnie będzie to zgodne z rzeczywistością. Uważam jednakże, mając na uwadze drugi z elementów, które odróżnić mają hejt od mowy nienawiści, że nie należy do jego istoty, żeby taka intencja w komunikacie musiała być zawarta. Tak jak w przypadku mowy nienawiści znajduje ona uzasadnienie w jakiejś, choćby najprymitywniejszej ideologii, na którą może składać się bardzo zdawkowy zestaw poglądów, tak hejt może od tego źródła całkowicie się oderwać i mieć charakter przypadkowy. Wyzwanie kogoś od „pieprzonych Azjatów” może nie nieść ze sobą jakichkolwiek treści światopoglądowych, może być werbalnym odpowiednikiem uderzenia kogoś w twarz, wolnym od wyrażenia czegokolwiek poza tym, co bezpośrednio $\mathrm{w}$ danym akcie się przedstawia: chęci zadania drugiej osobie cierpienia. Zaplecze ideologiczne jest $w$ hejtach dopuszczalne, ale jego brak nie dyskwalifikuje takich wypowiedzi, jak ma to miejsce w przypadku mowy nienawiści.

Mowa nienawiści, do której konstytutywnych elementów należy jakaś światopoglądowa orientacja, dotycząca choćby wyrywkowego twierdzenia i nieskładająca się koniecznie na doktrynę, nie bez powodu odróżniana jest przez autorów od znieważenia (art. 216 k.k.) czy zniesławienia (art. 212 k.k.). Przy ocenie czy doszło do popełnienia tych przestępstw, bez znaczenia jest motywacja, jaką kieruje się sprawca $-\mathrm{w}$ tym szczególnym sensie, że u ich ideologicznych podstaw znajduje się obrona takich dóbr, jak cześć i godność ludzka, które mogą zostać naruszone także wtedy, gdy zniewaga bądź zniesławienie wyczerpują się w sobie, tj. gdy nie odwołują się do żadnej racji. Nienawiść jest w tym wymiarze swoistym odwróceniem drugiej formuły Kantowskiego imperatywu kategorycznego (Kant 1971: 20) - i ona stawia sobie człowieka za cel, nienawidzenie drugiego nie jest środkiem do czegokolwiek, nie nienawidzi się dla zysku, poklasku czy z nadzieją na spełnienie czyichś oczekiwań. Z tym celem jednak, sprzecznie z intencją Kanta, wiąże się chęć wymierzenia zła, jest to niejako więc postawienie się w roli diabła.

I tak, hejtem będzie np.: (1) umieszczony pod teledyskiem komentarz o treści „najgorszy utwór w historii, autorowi życzę zachorowania na AIDS i raka jednocześnie”; ale i (2) prostszy, zwrócony wprost do znajomego komunikat: „umrzyj w męczarniach”; podobnie (3) wyzywanie chłopaka w klasie od „pedałów”; czy (4) każda wypowiedź z szeregu obelg kierowanych w internecie pod adresem celebryty, który przytył. Dwa pierwsze przykłady z życzeniem czegoś złego wyraźnie podkreślają kazualny charakter hejtów. Co do piosenki (1) - trudno znaleźć ideę, która łączyłaby stworzenie przeciętnego dzieła z normą zalecającą cierpieć męki choroby jego twórcy. Oczywiście, można to sobie wyobrazić, podobnie jak można 
sobie wyimaginować system motywujący każdy sąd czy życzenie, wydaje się jednak, że często brak takiej zależności, że chodzi tu tylko o werbalne ukierunkowanie nienawiści w konkretną stronę. Podobnie z życzeniem komuś śmierci w ogóle (2), doświadczenie uczy, że nie musi ono występować w związku z nienawiścią na tle rasowym, etnicznym, ksenofobicznym, religijnym itp. W przypadku dotyczącym wyzywania kogoś od „pedałów” (3), sprawa jest bardziej skomplikowana: dyskryminacja ze względu na orientację homoseksualną niejednokrotnie bywa wymieniana wśród idei wiązanych z mową nienawiści. Częstokroć, o czym zdarza się zapominać osobom zawodowo zajmującym się walką z tego rodzaju zjawiskami, wyzwisko takie pada ze względu na to, że w poczuciu hejtera dotkliwie skrzywdzi ono ofiarę, jednakże bez intencji przypisania komuś cechy bycia homoseksualistą czy wypowiedzenia ogólnego sądu co do takich osób. Hejt jest w takiej sytuacji tylko narzędziem służącym wyrządzaniu krzywdy, która motywowana może być w najróżniejszy sposób. Inną kwestią jest, dlaczego tak się dzieje i jak temu przeciwdziałać, czy jak chociaż zmniejszać skalę zjawiska. Zapewne w szeregu obelg mających sugerować bycie homoseksualistą znaczna część wprost egzemplifikuje mowę nienawiści na tle homofobicznym, niejednokrotnie jednak, zwłaszcza wśród dzieci, z inwektywami takimi nie idzie w parze żaden pogląd. Podobnie $\mathrm{z}$ internetowymi atakami na otyłe gwiazdy (4), najczęściej chodzi o zadanie im cierpienia i choć popularne obecnie ideologie żarliwie postulują zdrowy tryb życia, to nie nawołują one do nienawidzenia i pogardy w stosunku do tych, którzy imperatywowi temu nie czynią zadość, raczej zalecając niesienie im pomocy i odpowiednią motywację. I tutaj wyobrazić sobie można jakąś doktrynę, choćby w duchu konceptów wulgaryzujących (bądź nie) myśl nietzscheańską, konstruującą ideę człowieka doskonałego, zgodnie z którą osoba otyła, jako niepotrafiąca panować nad instynktami, godna jest pogardy. Mam jednakże ogromne wątpliwości co do tego, czy taki zamiar towarzyszył tym, którzy zalewali hejtami posty dotyczące Olafa Lubaszenki (Szewczyk 2015: b.s.). Jest to raczej kolejny z niezliczonych dowodów na to, że każdą nieprawość można uzasadnić.

Z powyższego wynika, że dla oceny tego, czy komunikat językowy stanowi hejt, czy mowę nienawiści, konieczne jest usytuowanie go w odpowiednim kontekście. Jeżeli mamy do czynienia z dłuższą wypowiedzią, której autor dowodzi, że Australijczycy to naród bandytów i najeźdźców, popierając takie twierdzenia zestawem argumentów, kolejno łącząc wyniki badań z sądem nawołującym do nienawiści na tym tle, mówić należy o mowie nienawiści, która nie nosi znamion hejtu. Jeżeli komunikat zawiera element indywidualno-konkretny i łączy jednostkę z pewną całością, zagrzewając do jej gorszego traktowania, np. poprzez słowa: „Kowalski to Polak, na pewno nas okradnie, trzeba trzymać się od niego z daleka, zresztą jak od 
wszystkich Polaków" - mamy do czynienia z hejtem, który jest zarazem mową nienawiści. Gdy z kolei brak elementu ideologicznego, jak w wyzwiskach typu „Ty gimbusie!", wtedy właściwie jest powiedzieć, że to hejt, który nie jest mową nienawiści.

\section{Zakończenie}

Mając na uwadze cały wywód, proponuję więc, by za hejt uznawać te z komunikatów językowych, w których zawarta jest - niezależnie od tego, czy doktrynalnie uzasadniona - nienawiść zwrócona ku podmiotom dającym się jednostkowo oznaczyć. Jednocześnie pragnę podkreślić, iż hejt ma charakter nieobliczalny, praktycznie daje się wyjaśnić dopiero po fakcie i na ogół nie sposób go przewidzieć.

Czynione rozważania tylko prowokują dalszą dyskusję. Nasuwa się choćby postulat rozstrzygnięcia tego, czy hejty mogą przyczynić się dobrej sprawie i czy moralnie okoliczność taka by je usprawiedliwiała. Rysuje się potrzeba odniesienia hejtu do aspektów aktów mowy (illokucyjnego i perlokucyjnego), a przez to i do kwestii osobistego zaangażowania hejterów. Powstaje pytanie, czy w momencie, gdy tworzą oni w internecie nienawistne komentarze na zlecenie i za pieniądze pozostając zupełnie obojętnymi jeśli chodzi o własne zdanie - winni być w ogóle nazywani hejterami? Sprawa okazuje się złożona, zaś jej rozstrzygnięcie uzależnione jest $\mathrm{w}$ istotnej mierze od odpowiedzi na pytanie o stosunek manifestacji uczucia do rzeczywistego doznania (podobnie jak wtedy, gdy zastanawiamy się nad tym, czy można mówić o nieszczerym wyznaniu miłosnym albo gdy rozważamy, czy faktycznie płaczą po zmarłym wynajęte w tym celu płaczki).

Wyrażam nadzieję, że czynione rozważania mogą stanowić punkt odniesienia i drogowskaz w próbie odpowiedzi na którekolwiek z tych i podobnych pytań. 


\section{Bibliografia}

Bobrowicz Alicja (2015), Prof. Bralczyk: Łatwiej hejtować niż nienawidzić. O zawrotnej karierze słowa „hejt”, MetroCafe.pl, http://metrocafe.pl/metrocafe/1,145523, 18801439,prof-bralczyk-latwiej-hejtowac-niz-nienawidzic-o-zawrotnej.html [dostęp: 10.02.2016].

Kant Immanuel (1971), Uzasadnienie metafizyki moralności, PWN, Warszawa.

Kołakowski Leszek (1986), Obecność mitu, Prószyński i S-ka, Warszawa.

Kołakowski Leszek (1990), Wychowanie do nienawiści, wychowanie do godności [w:] tegoż, Cywilizacja na ławie oskarżonych, Res Publica, Warszawa.

Kołakowski Leszek (2011), Śmierć utopii na nowo rozważona [w:] tegoż, Moje stuszne poglądy na wszystko, Wydawnictwo Znak, Kraków.

Kućka Michał, Pałka Katarzyna (2010), Ochrona przed mowa nienawiści - powództwo cywilne czy akt oskarżenia? [w:] A. Bodnar, A. Gliszczyńska-Grabias, R. Wieruszewski, M. Wyrzykowski (red.), Mowa nienawiści a wolność słowa. Aspekty prawne i społeczne, Oficyna 2010, LEX nr 121580.

Majdan Krzysztof (2012), Janusz Ławrynowicz vel „Pan Andrzej”. Internet go zniszczył. Miał stan przedzawałowy i chodził do psychiatry, http://natemat. pl/26741, janusz-lawrynowicz-vel-pan-andrzej-internet-go-zniszczyl-mialstan-przedzawalowy-i-chodzil-do-psychiatry [dostęp: 10.02.2016].

Platon (1957), Uczta, przeł. W. Witwicki, PWN, Warszawa.

Szewczyk Paula (2015), Olaf Lubaszenko: Bycie facetem z problemami to wstyd, http://stylzycia.newsweek.pl/olaf-lubaszenko-ksiazka-chlopaki-niech-placzakryzys,artykuly,365324,1.html [dostęp: 10.02.2016].

Szymborska Wisława (1997), Nienawiść [w:] tejże, Widok z ziarnkiem piasku, Wydawnictwo a5, Poznań.

Council of Europe Recommendation $n r$ R (97) 20 of the Committee of Ministers to Member States on "Hate Speech" (adopted on 30 October 1997) (b.r.), http://www. coe.int/t/dghl/standardsetting/hrpolicy/other_committees/dh-lgbt_docs/CM_ Rec\%2897\%2920_en.pdf [dostęp: 10.02.2016]. 


\title{
Adam Olczyk
}

\section{Czym jest hejt? Kilka słów o werbalnej nienawiści}

What is "Hejt"? A few Words about Verbal Hate

Słowa kluczowe: hejt, mowa nienawiści, nienawiść, Leszek Kołakowski

Key words: hejt, hate speech, hate, Leszek Kołakowski

\section{Streszczenie}

W artykule przedstawiona zostaje propozycja rozumienia słowa hejt w języku polskim. Pierwsza część rozważań poświęcona jest wyjaśnieniu zjawiska nienawiści, $\mathrm{z}$ akcentem na przypadkowy charakter tego uczucia (w tym zakresie następuje bezpośrednie odniesienie do hejtu). Kolejno hejt zostaje przyłożony do prawnego pojęcia "mowa nienawiści”, w związku z czym zostają wyróżnione dwie jego podstawowe cechy: (1) ukierunkowanie na jednostkę oraz (2) brak konieczności istnienia zaplecza ideologicznego.

\begin{abstract}
This article is an attempt to analyze the Polish word "hejt" from a philosophical, nonetymological point of view. The author tries to submit a definite way to understand that word. "Hejt" is described as a lingual statement which contains hate that is directed at what it relates to. For that purpose the analysis focuses on the attributes of hate, such as fortuitousness and insatiability. In sequence "hejt" is compared to the legal term "hate speech", therefore the author finds two basic features of it: (1) focusing at the individual, and (2) optional presence of an ideological background.
\end{abstract}

